\title{
Serangan Arthroschista hilaralis Walk. (Lepidoptera: Pyralidae) pada tegakan jabon (Neolamarckia cadamba [Roxb.] Bosser) di Sumatera Selatan
}

\author{
Infestation of Arthroschista hilaralis Walk. (Lepidoptera: Pyralidae) \\ at jabon plants (Neolamarckia cadamba [Roxb.] Bosser) \\ in South Sumatra
}

\author{
Sri Utami ${ }^{*}$, Hermanu Triwidodo ${ }^{2}$, Pudjianto ${ }^{2}$, Aunu Rauf ${ }^{2}$, \\ Noor Farikhah Haneda ${ }^{3}$
}
${ }^{1}$ Balai Penelitian dan Pengembangan Lingkungan Hidup dan Kehutanan Palembang Jalan Kol. Burlian KM 6,5 Puntikayu, Palembang 30151
${ }^{2}$ Departemen Proteksi Tanaman, Fakultas Pertanian, Institut Pertanian Bogor Jalan Kamper, Kampus IPB Dramaga, Bogor 16680
${ }^{3}$ Departemen Silvikultur Tropika, Fakultas Kehutanan, Institut Pertanian Bogor Jalan Lingkar Kampus, Kampus IPB Dramaga, Bogor 16680

(diterima Maret 2017, disetujui Desember 2017)

\begin{abstract}
ABSTRAK
Serangan hama merupakan masalah utama yang dihadapi dalam budi daya jabon (Neolamarckia cadamba [Roxb.] Bosser) di Indonesia khususnya di Sumatera Selatan. Arthroschista hilaralis Walk. (Lepidoptera: Pyralidae) merupakan salah satu hama penting yang menyerang tanaman jabon. Informasi mengenai tingkat serangan $A$. hilaralis pada tegakan jabon diperlukan sebagai bahan pertimbangan pengelolaan $A$. hilaralis. Tujuan penelitian ini adalah mengkaji insidensi dan intensitas serangan $A$. hilaralis yang menyerang tegakan jabon umur 2 dan 4 tahun selama 2 musim pengamatan, serta mengkaji pengaruh faktor cuaca (suhu dan kelembaban udara) terhadap serangan A. hilaralis. Penelitian ini dilaksanakan pada 6 lokasi yang terletak pada beberapa daerah di Sumatera Selatan. Pada setiap lokasi penelitian ditentukan 3 plot masing-masing seluas 0,03 ha dan berisi 20 tanaman jabon. Pengamatan insidensi dan intensitas serangan $A$. hilaralis dilakukan sebulan sekali selama 16 bulan yang mewakili 2 kategori waktu pengamatan, yaitu musim hujan dan musim kemarau. Hasil penelitian menunjukkan bahwa serangan $A$. hilaralis paling tinggi terjadi pada tegakan jabon umur 2 tahun dan pada musim hujan dengan insidensi dan intensitas serangan masing-masing sebesar $74,45 \%$ dan $55,21 \%$. Faktor cuaca (suhu dan kelembaban udara) berpengaruh terhadap tingkat serangan A. hilaralis. Suhu udara berkorelasi negatif terhadap insidensi $(\mathrm{r}=-0,629 ; \mathrm{p}=0,009)$ dan intensitas serangan $A$. hilaralis $(\mathrm{r}=$ -0,546; $\mathrm{p}=0,029)$, sedangkan kelembaban udara berkorelasi positif terhadap insidensi $(\mathrm{r}=0,900 ; \mathrm{p}<$ $0,0001)$ dan intensitas serangan $A$. hilaralis $(\mathrm{r}=0,768 ; \mathrm{p}=0,0005)$.
\end{abstract}

Kata kunci: Arthroschista hilaralis, Neolamarckia cadamba, serangan hama 
intensity level of $A$. hilaralis on jabon stands at the planting age 2 and 4 years at the 2 seasons, and analyze the effect of weather (temperature and humidity) to foliar damage caused by $A$. hilaralis. This experiment was conducted in six locations in South Sumatra. The plots were delineated in three area that each plot was 0.03 ha in area and contain 20 jabon trees. Observations on the incidence and intensity level of $A$. hilaralis were conducted every month for 16 months representing two categories of time point observation of the rainy season and dry season. The results showed that infestation of $A$. hilaralis on jabon stands at the planting age 2 years and the rainy season was higher than planting age 4 years and another season. The incidence level and intensity level of $A$. hilaralis were $74.45 \%$ and $55.21 \%$ respectively. Weather factors (e.g. temperature and humidity) thought affected the incidence level and intensity level of A. hilaralis. Temperature has negative correlation to the incidence level of $A$. hilaralis ( $\mathrm{r}=-0.629 ; \mathrm{p}=0.009)$ and to the intensity level of A. hilaralis $(\mathrm{r}=-0.546 ; \mathrm{p}=0.029)$. Humidity has positive correlation to the incidence level of A. hilaralis $(\mathrm{r}=0.900 ; \mathrm{p}<0.0001)$ and to the intensity level of $A$. hilaralis $(\mathrm{r}=0.768 ; \mathrm{p}=0.0005)$.

Key words: Arthroschista hilaralis, infestation of pest, Neolamarckia cadamba

\section{PENDAHULUAN}

Jabon (Neolamarckia cadamba [Roxb.] Bosser) merupakan jenis pohon tropis yang sebaran alamnya dapat dijumpai di Indonesia, India, Australia, China, Malaysia, Papua Nugini, Filipina, Singapura, dan Vietnam (Orwa et al. 2009). Jabon juga telah berhasil diintroduksikan di Kosta Rika, Puerto Riko, Afrika Selatan, Suriname, Taiwan, Venezuela, dan negara-negara subtropis dan tropis lainnya (Orwa et al. 2009). Menurut Slik (2006), jabon telah ditanam di Indonesia dalam skala besar sejak tahun 1930an. Tanaman ini juga telah dibudidayakan di Jawa (terutama di Jawa Barat dan Jawa Timur), Kalimantan (terutama di Kalimantan Selatan dan Kalimantan Timur), Sumatera (hampir tersebar di seluruh provinsi), Sulawesi (hampir tersebar di seluruh provinsi), Sumbawa (Nusa Tenggara Barat), dan Papua (Irian Jaya) (Martawijaya et al. 1989).

Kayu jabon banyak digunakan untuk korek api, kayu lapis, peti pembungkus, cetakan beton, mainan anak-anak, pulp, dan kertas. Kayu jabon dapat digunakan untuk lapisan depan dan belakang kayu lapis, bahan konstruksi, bahan baku papan partikel atau bubur kertas, dan kegunaan lainnya (Mulyana \& Fahmi 2011). Daun jabon dapat digunakan sebagai obat. Chandel et al. (2012) dan Sari et al. (2014) melaporkan bahwa ekstrak daun jabon memiliki kegunaan sebagai obat terapi kanker. Pohon jabon juga berfungsi sebagai peneduh dan hiasan di tepi jalan, serta pelindung bagi tanaman lain pada sistem wanatani (Krisnawati et al. 2011).
Di Sumatera Selatan sebaran alam jabon hampir dijumpai di seluruh daerah dan banyak ditemukan berkelompok di sepanjang sepadan sungai (Sudrajat 2015). Jabon sudah dibudayakan dalam skala luas di Sumatera Selatan sejak tahun 2010. Tanaman ini dibudidayakan di hutan rakyat dan hutan tanaman industri (HTI). Salah satu kendala yang dihadapi dalam budi daya jabon, yaitu adanya serangan hama defoliator Arthroschista hilaralis Walk. (Lepidoptera: Pyralidae).

A. hilaralis telah lama dilaporkan menyerang tanaman jabon. Thapa (1970) melaporkan bahwa tegakan jabon di Sabah Malaysia terserang $A$. hilaralis. Thapa \& Bhandari (1976) melaporkan bahwa tegakan jabon yang dibudidayakan masyarakat di West Bengal-India terserang $A$. hilaralis. Pertanaman jabon di Bangladesh juga terserang hama ini (Baksha 2000). Utami et al. (2011) melaporkan bahwa jabon yang berumur kurang dari 1 tahun di Kawasan Hutan dengan Tujuan Khusus (KHDTK) Kemampo, Kabupaten Banyuasin, Provinsi Sumatera Selatan terserang $A$. hilaralis dengan rata-rata tingkat serangan sebesar 95\%. Ulat daun $A$. hilaralis juga menyerang pertanaman jabon di beberapa daerah di Pulau Jawa baik pada tegakan jabon yang ditanam di dataran rendah maupun dataran tinggi (Susanty 2014).

Dilaporkan serangan A. hilaralis dapat mempengaruhi tanaman jabon. Nair (2007) melaporkan bahwa serangan $A$. hilaralis dapat memperlambat pertumbuhan tanaman, menyebabkan terjadinya dieback (mati pucuk), dan terbentuknya cabang epikormik. Junaedi \& Pribadi (2011) melaporkan bahwa serangan $A$. hilaralis mempengaruhi 
pertumbuhan jabon sebesar $46 \%$ pada tegakan jabon berumur 2 tahun. Kegiatan pengelolaan $A$. hilaralis penting dilakukan untuk mencegah dan menekan serangan hama ini. Informasi mengenai serangan A. hilaralis pada tanaman jabon di hutan rakyat Sumatera Selatan masih belum tersedia. Oleh karena itu, penelitian mengenai tingkat serangan $A$. hilaralis sangat penting dilakukan dan hasil penelitian ini diharapkan dapat dijadikan sebagai informasi dasar dan bahan pertimbangan pengelolaan A. hilaralis pada tanaman jabon.

Penelitian ini bertujuan untuk mengkaji insidensi dan intensitas serangan $A$. hilaralis pada tegakan jabon umur 2 dan 4 tahun pada 2 musim pengamatan, serta mengkaji korelasi faktor cuaca (suhu dan kelembaban udara) terhadap insidensi dan intensitas serangan $A$. hilaralis.

\section{BAHAN DAN METODE}

\section{Penentuan lokasi dan plot pengamatan}

Penelitian dilakukan pada 6 lokasi penelitian di Sumatera Selatan (Gambar 1, Tabel 1). Penentuan lokasi berdasarkan kriteria kondisi tegakan jabon yang dibudidayakan masyarakat, ketinggian tempat tumbuh tanaman jabon, dan topografinya. Penentuan dan pemilihan tanaman jabon berdasarkan pada kesamaan asal bibit jabon dan teknik silvikultur yang diterapkan masyarakat. Tegakan jabon yang dibudidayakan masyarakat, bibitnya berasal dari Balai Perbenihan Tanaman Hutan (BPTH) Wilayah Sumatera Bagian Selatan di Palembang. Keenam lokasi penelitian tersebut termasuk dataran rendah dengan ketinggian kurang dari $100 \mathrm{~m}$ dpl dengan topografi yang relatif datar.

Tiga lokasi penelitian untuk pengamatan tegakan jabon umur 2 tahun terletak di Desa Sukatani, Kecamatan Tanjung Lago dan Desa Karanganyar, Kecamatan Banyuasin II, Kabupaten Banyuasin masing-masing seluas 2 ha, serta Kelurahan Kebun Bunga, Kecamatan Sukarame, Kota Palembang seluas 0,5 ha (Tabel 1 dan Gambar 1). Tiga lokasi pengamatan jabon umur 4 tahun terletak di Desa Tanjung Pering, Kecamatan Indralaya Utara, Kabupaten Ogan Ilir dan Desa Lingkis, Kecamatan Jejawi, Kabupaten Ogan Komering Ilir masing-masing seluas 1 ha, serta Desa Sritiga, Kecamatan Sumber Marga, Kabupaten Banyuasin seluas 2 ha (Tabel 1 dan Gambar 1). Pada setiap lokasi penelitian ditentukan 3 plot masing-masing seluas 0,03 ha dan berisi 20 tanaman jabon (Gambar 2).

\section{Pengumpulan data dan pengamatan tingkat serangan $A$. hilaralis}

Pengukuran tingkat serangan A. hilaralis dilakukan sebulan sekali selama 16 bulan pengamatan yang mewakili 2 kategori musim pengamatan, yaitu musim hujan dan musim kemarau, yaitu mulai Januari 2015 hingga Juli 2016. Pengamatan tingkat serangan meliputi

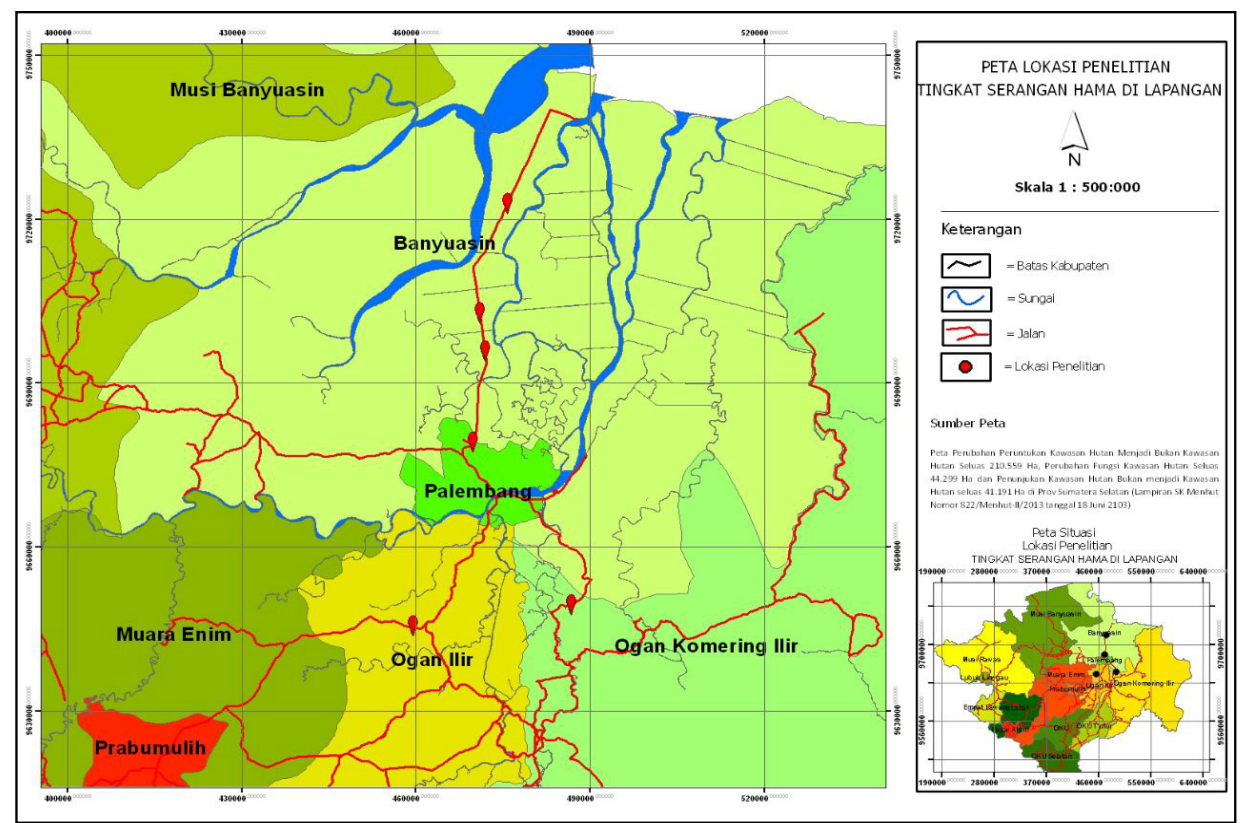

Gambar 1. Lokasi plot penelitian tegakan jabon pada beberapa daerah di Sumatera Selatan. 
Tabel 1. Lokasi penelitian pada tegakan jabon monokultur di Sumatera Selatan

\begin{tabular}{|c|c|c|c|c|c|c|}
\hline $\begin{array}{l}\text { Umur } \\
\text { tanaman } \\
\text { (tahun) }\end{array}$ & Lokasi & Koordinat & $\begin{array}{l}\text { Ketinggian } \\
(\mathrm{m} \text { dpl) }\end{array}$ & $\begin{array}{l}\text { Umur } \\
\text { tanaman } \\
\text { (tahun) }\end{array}$ & $\begin{array}{l}\text { Luas } \\
\text { (ha) }\end{array}$ & $\begin{array}{l}\text { Jarak tanam } \\
\quad(\mathrm{m})\end{array}$ \\
\hline 2 & $\begin{array}{l}\text { Desa Sukatani, Kecamatan Tanjung } \\
\text { lago, Kabupaten Banyuasin }\end{array}$ & $\begin{array}{l}02^{\circ} 41^{\prime} 14,99^{\prime \prime} \mathrm{LS} \\
104^{0} 44^{\prime} 18,4 \text { " BT }\end{array}$ & 13 & 2 & 2 & $3 \times 3$ \\
\hline 2 & $\begin{array}{l}\text { Desa Karanganyar, Kec. Banyuasin } \\
\text { II, Kab. Banyuasin }\end{array}$ & $\begin{array}{l}02^{0} 30^{\prime} 27,11^{\prime \prime} \mathrm{LS} \\
104^{0} 46^{\prime} 52,2 \text { '”BT }\end{array}$ & 12 & 2 & 2 & $3 \times 3$ \\
\hline 2 & $\begin{array}{l}\text { Kebun Bunga, Kec. Sukarame, Kota } \\
\text { Palembang }\end{array}$ & $\begin{array}{l}02^{0} 54^{\prime} 06,5^{\prime \prime} \mathrm{LS} \\
104^{0} 43^{\prime} 37,6^{\prime \prime} \mathrm{BT}\end{array}$ & 19 & 2 & 0,5 & $3 \times 3$ \\
\hline 4 & $\begin{array}{l}\text { Desa Tanjung Pering, Kec. Indralaya } \\
\text { Utara, Kab. Ogan Ilir }\end{array}$ & $\begin{array}{l}03^{0} 122^{\prime} 21,3^{\prime \prime} \mathrm{LS} \\
104^{0} 38^{\prime} 03^{\prime} 5^{\prime \prime} \mathrm{BT}\end{array}$ & 38 & 4 & 1 & $3 \times 3$ \\
\hline 4 & $\begin{array}{l}\text { Desa Sritiga, Kec. Sumber Marga, } \\
\text { Kab. Banyuasin }\end{array}$ & $\begin{array}{l}02^{0} 24^{\prime} 18,3^{\prime \prime} \mathrm{LS} \\
104^{0} 49^{\prime} 30,6^{\prime \prime} \mathrm{BT}\end{array}$ & 17 & 4 & 2 & $4 \times 3$ \\
\hline 4 & $\begin{array}{l}\text { Desa Lingkis, Kec. Jejawi, Kab. } \\
\text { Ogan Komering Ilir }\end{array}$ & $\begin{array}{l}03^{0} 10^{\prime} 25,7^{\prime \prime} \mathrm{LS} \\
104^{0} 51^{\prime} 42,4^{\prime \prime} \mathrm{BT}\end{array}$ & 22 & 4 & 1 & $4 \times 3$ \\
\hline
\end{tabular}

Tabel 2. Klasifikasi tingkat kerusakan tanaman (kriteria Unterstenhofer 1963)

\begin{tabular}{lcll}
\hline $\begin{array}{l}\text { Kategori } \\
\text { kerusakan (i) }\end{array}$ & $\begin{array}{c}\text { Nilai klasifikasi } \\
(\mathrm{v})\end{array}$ & \multicolumn{1}{c}{ Tanda kerusakan daun } & Tingkat kerusakan \\
\hline 1 & 0 & Kerusakan daun $\leq 5 \%$ & Sehat \\
2 & 1 & Kerusakan daun $5 \%<\mathrm{x} \leq 25 \%$ & Ringan \\
3 & 2 & Kerusakan daun $25 \%<\mathrm{x} \leq 50 \%$ & Agak berat \\
4 & 3 & Kerusakan daun $50 \%<\mathrm{x} \leq 75 \%$ & Berat \\
5 & 4 & Kerusakan daun $75 \%<\mathrm{x} \leq 100 \%$ & Sangat berat \\
\hline
\end{tabular}

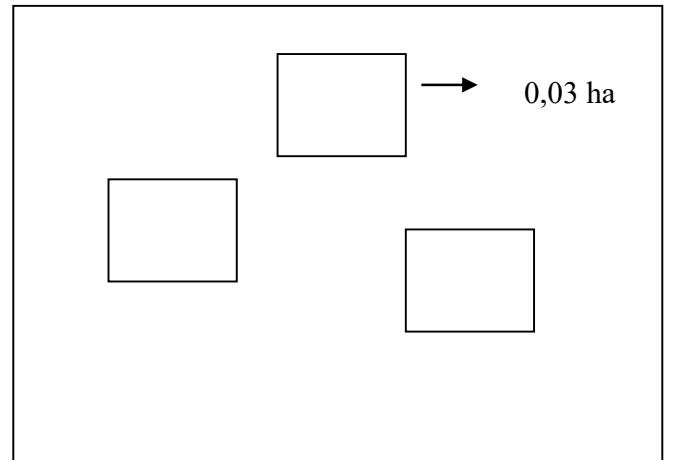

Gambar 2. Plot pengamatan pada setiap lokasi penelitian.

insidensi dan intensitas serangan $A$. hilaralis. Insidensi serangan $A$. hilaralis diartikan sebagai perbandingan antara jumlah pohon yang diserang A. hilaralis dan jumlah pohon yang ada di dalam satuan luas areal tertentu, dinyatakan dalam persen. Intensitas serangan A. hilaralis ditentukan dengan mengamati dan menghitung jumlah daun yang rusak pada setiap pohon kemudian dilakukan penilaian dengan menggunakan teknik skoring berdasarkan kriteria klasifikasi Unterstenhofer (1963) (Tabel 2).

$\begin{aligned} & \text { Insidensi } \\ & \text { serangan } \\ & \text { A. hilaralis }\end{aligned}=\frac{\begin{array}{c}\text { Jumlah tanaman yang } \\ \text { diserang }\end{array}}{\begin{array}{c}\text { Jumlah tanaman yang } \\ \text { diamati }\end{array}} \times 100 \%$

Intensitas serangan $A$. hilaralis dihitung dengan menggunakan rumus dibawah ini.

$$
\mathrm{IS}=\frac{\sum(\mathrm{ni} \times \mathrm{v})}{\mathrm{Z} \times \mathrm{N}} \times 100 \%, \text { dengan }
$$

IS: intensitas serangan hama; n: jumlah tanaman yang terserang dengan klasifikasi tertentu; v: nilai untuk klasifikasi tertentu; i: kategori kerusakan tanaman pada daun; $\mathrm{N}$ : jumlah tanaman seluruhnya dalam suatu petak contoh; Z: nilai tertinggi dalam klasifikasi.

\section{Analisis data}

Untuk melihat perbedaan antara umur tegakan jabon dan musim pengamatan, data dianalisis dengan menggunakan sidik ragam ANOVA dan nilai tengah diuji Duncan pada taraf 0,05 dengan program Statistical Analysis System (SAS) 9.1.3. Untuk melihat keterkaitan faktor suhu dan kelembaban udara terhadap insidensi dan 
intensitas serangan $A$. hilaralis dianalisis korelasi menggunakan program SAS 9.1.3. Analisis regresi dilakukan untuk melihat pengaruh faktor suhu dan kelembaban udara terhadap insidensi dan intensitas serangan A. hilaralis dalam suatu persamaan linear regresi dengan menggunakan program SAS 9.1.3 (SAS Institute 2010).

\section{HASIL}

\section{Tingkat serangan $A$. hilaralis}

Hasil penelitian menunjukkan bahwa tegakan jabon yang ditanam masyarakat umur 2 dan 4 tahun terserang ulat daun $A$. hilaralis. Ulat $A$. hilaralis menyerang daun dengan cara melipat daun baik satu daun atau beberapa daun. Dalam satu daun bisa ditemukan satu atau lebih ulat dengan beberapa jenis instar/stadia. Serangan ulat biasanya dimulai dari cabang pohon kedua dari apikal kemudian bisa menyebar ke cabang pohon di bawahnya.

Insidensi serangan $A$. hilaralis paling tinggi terjadi pada tegakan jabon umur 2 tahun dan pada musim hujan, yaitu sebesar $74,45 \%$, sedangkan paling rendah pada tegakan jabon umur 4 tahun dan pada musim kemarau sebesar 45,99\% (Tabel 3). Intensitas serangan A. hilaralis berbeda antar umur tanaman jabon (Tabel 4). Intensitas serangan A. hilaralis paling tinggi terjadi pada tegakan jabon umur 2 tahun dan pada musim hujan sebesar $55,21 \%$, sedangkan paling rendah pada tegakan jabon umur 4 tahun dan pada musim kemarau sebesar 24,45\% (Tabel 4).

Berdasarkan analisis korelasi pearson menunjukkan bahwa insidensi serangan $A$. hilaralis berkorelasi positif terhadap intensitas serangannya baik pada tegakan jabon umur 2 tahun $(\mathrm{r}=0,878$; $\mathrm{P}$ $<0,0001)$ maupun 4 tahun $(\mathrm{r}=0,906 ; \mathrm{P}<0,0001)$ dan menunjukkan korelasi nyata pada taraf $1 \%$ (Tabel 5).

\section{Pengaruh suhu dan kelembaban udara terhadap tingkat serangan $\boldsymbol{A}$. hilaralis}

Rata-rata suhu dan kelembaban udara selama penelitian berkisar antara $25-29{ }^{\circ} \mathrm{C}$ dan $71-85 \%$. Pada saat musim kemarau (Juli hingga Oktober 2015) terjadi kebakaran hutan dan lahan di Sumatera Selatan. Rata-rata suhu dan kelembaban udara selama musim kebakaran hutan masingmasing sebesar $28,26^{\circ} \mathrm{C}$ dan $74,2 \%$.

Suhu udara berkorelasi negatif terhadap insidensi A. hilaralis $(\mathrm{r}=-0,629 ; \mathrm{P}=0,009)$ dan intensitas serangan $A$. hilaralis $(\mathrm{r}=-0,546 ; \mathrm{P}$ $=0,029)$ (Gambar 3A dan 3B). Berdasarkan persamaan regresi menunjukkan bahwa penurunan

Tabel 3. Rata-rata insidensi serangan Arthroschista hilaralis pada tegakan jabon

\begin{tabular}{lccc}
\hline \multirow{2}{*}{ Umur tanaman (tahun) } & \multicolumn{2}{c}{ Rata-rata insidensi serangan A. hilaralis (\%) \pm simpangan baku } \\
\cline { 2 - 3 } & Musim hujan & Musim kemarau & Antar umur tanaman \\
\hline 2 & $74,45 \pm 0,64$ & $54,86 \pm 16,35$ & $64,65 \pm 14,91$ \\
4 & $61,53 \pm 18,35$ & $45,99 \pm 20,93$ & $53,76 \pm 19,56$ \\
\hline Antar musim & $67,99 \pm 13,59$ & $50,42 \pm 17,49$ & \\
\hline
\end{tabular}

Tabel 4. Rata-rata intensitas serangan Arthroschista hilaralis pada tegakan jabon

\begin{tabular}{lccc}
\hline \multirow{2}{*}{ Umur tanaman (tahun) } & \multicolumn{2}{c}{ Rata-rata intensitas serangan A. hilaralis $(\%) \pm$ simpangan aku } \\
\cline { 2 - 3 } & Musim hujan & Musim kemarau & Antar umur tanaman \\
\hline 2 & $55,21 \pm 14,23$ & $54,49 \pm 9,84$ & $54,85 \pm 10,95 \mathrm{a}$ \\
4 & $29,26 \pm 12,69$ & $24,45 \pm 1,72$ & $26,85 \pm 8,52 \mathrm{~b}$ \\
\hline Antar musim & $42,23 \pm 18,64$ & $39,47 \pm 17,63$ & \\
\hline
\end{tabular}

Angka yang diikuti dengan huruf yang sama, tidak berbeda nyata pada $\alpha=5 \%$ (uji selang berganda Duncan).

Tabel 5. Hasil analisis korelasi antara insidensi dan intensitas serangan Arthroschista hilaralis

\begin{tabular}{lcc}
\hline Korelasi & Koefisien korelasi & P-Value \\
\hline Persentase dengan intensitas serangan hama pada jabon umur 2 tahun & $0,878^{* *}$ & $<0,0001$ \\
Persentase dengan intensitas serangan hama pada jabon umur 4 tahun & $0,906 * *$ & $<0,0001$ \\
\hline
\end{tabular}

**: korelasi signifikan pada level 0,01. 
suhu akan diikuti dengan kenaikan tingkat serangan A. hilaralis. Nilai slope/koefisien regresi sebesar $-41,59$ berarti setiap kenaikan 1 derajat suhu maka rata-rata insidensi serangan $A$. hilaralis akan turun sebesar $41,59 \%$. Nilai slope sebesar 19,72 menunjukkan bahwa setiap kenaikan 1 derajat suhu maka rata-rata intensitas serangan A. hilaralis akan turun sebesar $19,72 \%$. Nilai $\mathrm{R}$ determinan suhu terhadap insidensi dan intensitas serangan $A$. hilaralis lebih rendah dibandingkan dengan $\mathrm{R}$ determinan kelembaban terhadap insidensi dan intensitas serangan A. hilaralis.

Kelembaban udara berkorelasi positif terhadap insidensi $(\mathrm{r}=0,900 ; \mathrm{P}<0,0001)$ dan intensitas serangan A. hilaralis $(\mathrm{r}=0,768 ; \mathrm{P}=$ 0,0005) (Gambar 3C dan 3D). Kelembaban udara berbanding lurus terhadap insidensi dan intensitas serangan $A$. hilaralis sehingga peningkatan kelembaban akan diikuti dengan peningkatan tingkat serangan $A$. hilaralis. Nilai slope sebesar

A

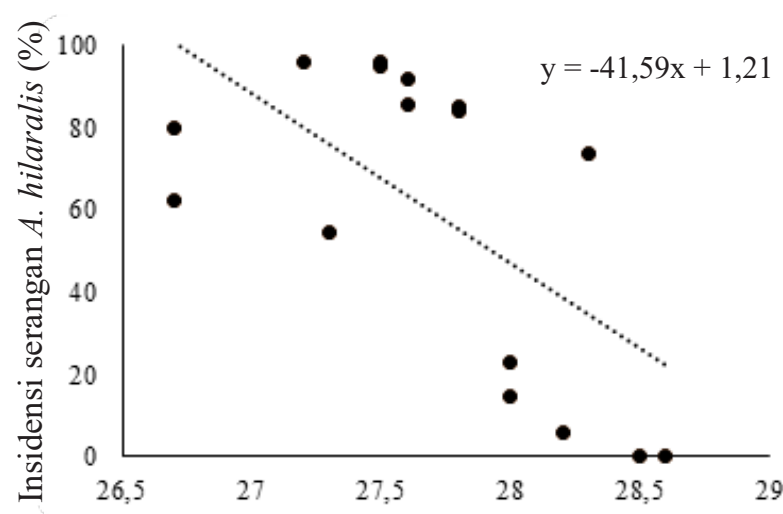

7,20 berarti setiap kenaikan 1 persen kelembaban maka rata-rata insidensi serangan $A$. hilaralis akan naik sebesar 7,20\%. Nilai slope sebesar 3,36 menunjukkan bahwa setiap kenaikan 1 persen kelembaban maka rata-rata intensitas serangan $A$. hilaralis akan naik sebesar 3,36\%.

\section{PEMBAHASAN}

A. hilaralis menyerang tegakan jabon baik pada tanaman berumur muda maupun berumur tua. Tingkat serangan A. hilaralis pada tanaman jabon umur 2 tahun lebih tinggi dibandingkan dengan jabon umur 4 tahun. Tegakan jabon umur 2 tahun lebih rentan terserang $A$. hilaralis dibandingkan dengan tegakan jabon berumur 4 tahun. Terdapat beberapa jenis serangga herbivor yang lebih menyukai tanaman yang berumur lebih muda dibandingkan dengan tanaman yang berumur tua

B

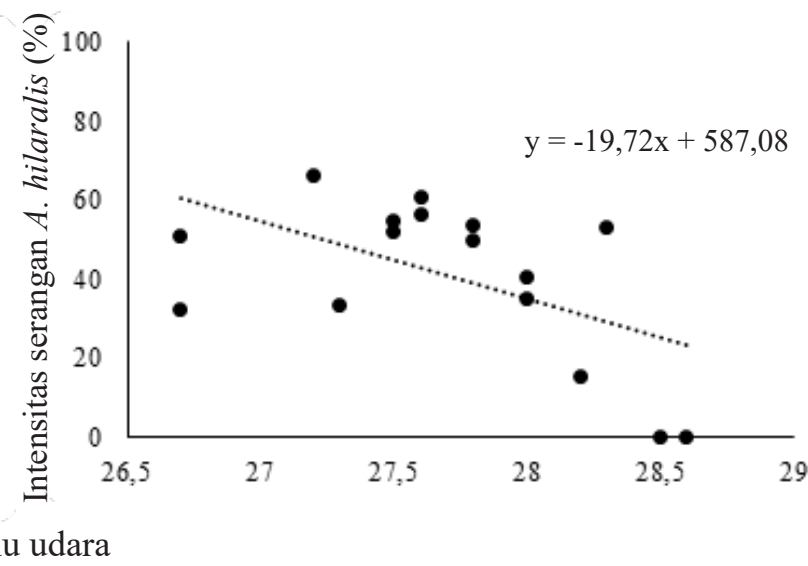

D

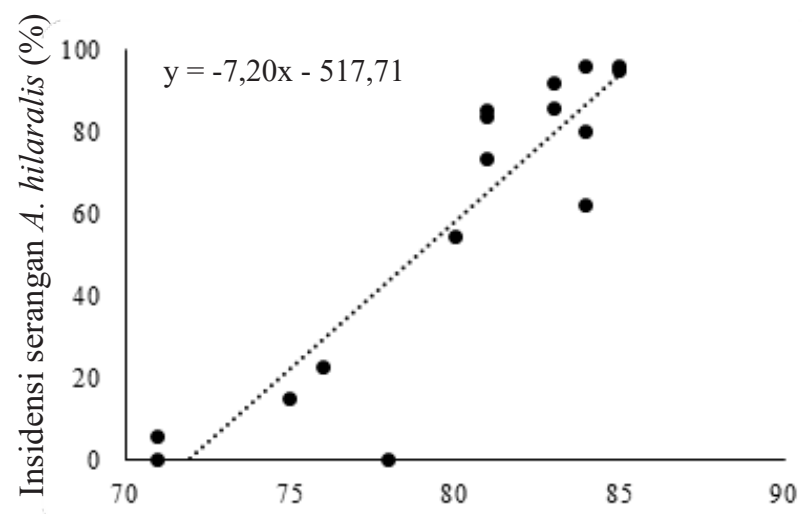

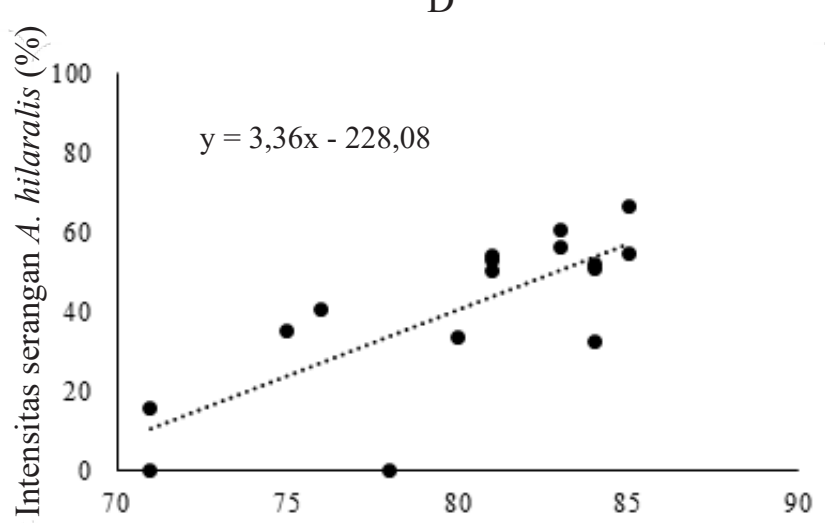

Kelembaban udara

Gambar 3. Hubungan antara suhu udara dan insidensi serangan Arthroschista hilaralis (A) dan intensitas serangan $A$. hilaralis (B); hubungan antara kelembaban udara dan insidensi serangan $A$. hilaralis (C) dan intensitas serangan $A$. hilaralis (D). 
(Mitchell et al. 2016). Price (1991) melaporkan bahwa tanaman tahunan yang berumur lebih muda dan vigor lebih tahan terhadap serangan serangga herbivor dibandingkan dengan tanaman yang lebih tua. Speight et al. (2008) melaporkan bahwa beberapa larva lepidoptera lebih menyukai tanaman muda dibandingkan dengan tanaman yang lebih tua karena vigor dan sedikitnya trikoma pada tanaman muda mempengaruhi perilaku serangga tersebut. Sebagai contoh ulat Dioryctria ponderosae Dyar (Lepidoptera: Pyralidae) lebih banyak menyerang tanaman Pinus ponderosa yang berumur muda dengan diameter kurang dari $20 \mathrm{~cm}$ dibandingkan dengan tanaman pinus yang lebih tua (Price 1991). Selain itu, Peltonen \& Heliovaara (1998) melaporkan bahwa besarnya insidensi serangan Cryphalus saltuarius Weise bergantung pada umur tanaman, dimana $C$. saltuarius lebih banyak menyerang pohon pinus (Pinus sylvestris) umur 1 tahun dibandingkan dengan pinus yang berumur lebih tua pada hutan tanaman campuran antara pinus (P. sylvestris), spruce (Picea abies), dan birch (Betula spp.) di Finlandia.

Musim hujan dengan curah hujan dan hari hujan lebih banyak dibandingkan dengan musim kemarau, lebih mendukung serangan $A$. hilaralis pada tanaman jabon. BMKG (2016) melaporkan bahwa besarnya curah hujan pada musim kemarau dan musim hujan masing-masing sebesar 97,08 $\mathrm{mm} /$ bulan dan 225,58 $\mathrm{mm} /$ bulan; dengan hari hujan pada musim kemarau dan musim hujan masing-masing sebesar 5,88 hari/bulan dan 14,58 hari/bulan. Serangan A. hilaralis pada tanaman jabon dijumpai menyerang musim hujan, yaitu pada bulan Oktober 2015 hingga Januari 2016 dan serangannya meningkat pada musim hujan pada bulan Februari hingga Mei 2016. Di Malaysia, A. hilaralis meningkat serangannya pada bulan November hingga Januari (Thapa 1970). Serangan A. hilaralis ini serupa dengan serangan hama defoliator lainnya, seperti Hyblaea puera (Cramer) (Lepidoptera: Hyblaeidae) yang mulai menyerang tanaman jati pada bulan Juli-Agustus dan mencapai puncak serangan selama musim hujan di India (Wylie \& Speight 2012). Di Indonesia, H. puera menyerang tanaman jati mulai bulan November hingga Januari (Husaeni et al. 2006).

Wylie \& Speight (2012) melaporkan bahwa populasi sebagian besar hama defoliator pada saat musim hujan lebih banyak dibandingkan dengan musim kemarau. Pada saat musim hujan, akan banyak tumbuh terubusan sehingga hama defoliator tersebut menyukai daun-daun muda yang baru tumbuh (Speight et al. 2008). Berdasarkan pengamatan di lapang menunjukkan bahwa A. hilaralis lebih banyak menyerang pada daun-daun muda terutama pada bagian apikal tanaman dan bagian ujung dari cabang atau ranting tanaman. Daun-daun yang lebih tua kurang disukai A. hilaralis. Bila daun-daun muda sudah terbatas jumlahnya, A. hilaralis melakukan mobilitas untuk makan daun yang lebih tua.

Kejadian kebakaran hutan dan lahan yang terjadi selama musim kemarau tahun 2015 diduga juga memberikan pengaruh terhadap serangan $A$. hilaralis. Kebakaran hutan memberikan dampak terhadap lingkungan, yaitu kematian hewan dan tumbuhan yang disebabkan panas dan asap selama kebakaran (Gerson \& Kelsey 1997) dan memberikan efek secara tidak langsung terhadap struktur vegetasi dan keberadaan spesies pada periode setelah kebakaran (Pickering 1997). Elia et al. (2012) melaporkan bahwa diantara komunitas ekologi, serangga merupakan bioindikator penting dalam kejadian pasca kebakaran hutan dan lahan. Kelimpahan serangga Ordo Lepidoptera menurun drastis selama 2 tahun pasca kebakaran di hutan oak (Elia et al. 2012).

Berdasarkan analisis korelasi menunjukkan bahwa suhu udara dan kelembaban udara memberikan pengaruh terhadap besarnya insidensi dan intensitas serangan A. hilaralis. Suhu udara berpengaruh negatif terhadap insidensi dan intensitas serangan $A$. hilaralis, sedangkan kelembaban udara berpengaruh positif terhadap insidensi dan intensitas serangan A. hilaralis.

Perkembangan dan outbreak hama terjadi karena interaksi faktor biotik, abiotik (termasuk iklim), dan manajemen budi daya (Ali et al. 2014; Li et al. 2015). Klapwijk et al. (2012), Chen et al. (2014), serta Macfadyen et al. (2016) melaporkan bahwa perkembangan populasi hama sangat dipengaruhi oleh kondisi iklim, seperti suhu udara, kelembaban relatif udara, curah hujan, dan kelembaban tanah. Nair (2007) melaporkan bahwa serangan $A$. hilaralis yang menyerang tanaman jabon sangat dipengaruhi oleh faktor cuaca. Pribadi \& Anggraeni (2011) melaporkan bahwa suhu dan kelembaban sangat mempengaruhi tingkat kerusakan A. hilaralis pada tegakan jabon. Tingkat kerusakan daun oleh $A$. hilaralis pada HTI jabon sektor Baserah Kabupaten Kuansing, Provinsi 
Riau, menunjukkan korelasi positif terhadap kelembaban dan negatif terhadap temperatur (Pribadi \& Anggraeni 2011).

Berdasarkan hasil penelitian tersebut yang perlu diperhatikan oleh pengambil kebijakan pengelola hama atau pengelola hutan, kegiatan monitoring $A$. hilaralis wajib dilakukan secara berkala dan terus-menerus. Kegiatan monitoring mutlak dilakukan terutama menjelang musim hujan dan pada saat musim hujan, untuk memantau keberadaan dan tingkat serangan $A$. hilaralis, serta musuh alaminya. Pada saat melakukan kegiatan monitoring hendaknya juga dilakukan pengamatan terhadap pertumbuhan tanaman jabon.

\section{KESIMPULAN}

Serangan A. hilaralis dipengaruhi beberapa faktor diantaranya umur tanaman dan faktor cuaca (suhu dan kelembaban udara). Serangan A. hilaralis paling tinggi terjadi pada tegakan jabon umur 2 tahun dan pada musim hujan dengan insidensi dan intensitas serangan masingmasing sebesar $74,45 \%$ dan $55,21 \%$. Suhu dan kelembaban memberikan pengaruh terhadap besarnya serangan $A$. hilaralis. Suhu berkorelasi negatif terhadap insidensi dan intensitas serangan A. hilaralis, sedangkan kelembaban berkorelasi positif terhadap insidensi dan intensitas serangan A. hilaralis.

\section{UCAPAN TERIMA KASIH}

Ucapan terima kasih disampaikan kepada Pusat Pendidikan dan Pelatihan Sumber Daya Manusia Kementerian Lingkungan Hidup dan Kehutanan yang telah memberikan beasiswa dan bantuan dana penelitian.

\section{DAFTAR PUSTAKA}

Ali MPDH, Nachman G, Ahmed N, Begum MA, Rabbi MF. 2014. Will climate change affect outbreak patterns of planthoppers in Bangladesh? Plos One 9, e91678. doi: https://doi.org/10.1371/ journal.pone.0091678.

Baksha MW. 2000. Biology, ecology, and management of kadam defoliator Arthroschista hilaralis (Pyralidae: Lepidoptera) in Bangladest. Journal of Forest Science 29:133-136.

[BMKG] Badan Meteorogi Klimatologi dan Geofisika Sumatera Selatan. 2016. Data Cuaca di Sumatera Selatan Tahun 2015-2016. Palembang: BMKG Sumsel.

Chandel M, Sharma U, Kumar N, Singh B, Kaur S. 2012. Antioxidant activity and identification of bioactive compounds from leaves of Anthocephalus cadamba by ultra performance liquid chromatography/electropray ionization quadruploe time of flight mass spectrometry. Asian Pasific Journal of Tropical Medicine 5: 977-985. doi: https://doi.org/10.1016/S19957645(12)60186-2.

Chen C, Xia QW, Fu S, Wu XF, Xue FS. 2014. Effect of photoperiod and temperature on the intensity of pupal diaupause in the cotton bollworm, Helicoverpa armigera (Lepidoptera: Noctuidae). Bulletin of Entomological Research 104:12-18. doi: https://doi.org/10.1017/ S0007485313000266.

Elia M, Lafortezza R, Tarasco E, Colangelo G, Sanesi G. 2012. The spatial and temporal effects of fire on insect abundance in Mediterranean forest ecosystems. Forest Ecology and Management 263:262-267. doi: https://doi.org/10.1016/j. foreco.2011.09.034.

Gerson EA, Kelsey RG. 1997. Attraction and direct mortality of Pandora moths Coloradia pandora (Lepidoptera: Saturniidae), by nocturnal fire. Forest Ecology and Management 98:71-75. doi: https://doi.org/10.1016/S0378-1127(97)00088-1.

Husaeni EA, Kasno, Haneda NF, Rachmatsjah O. 2006. Pengantar Hama Hutan di Indonesia: Bioekologi dan Teknik Pengendalian. Bogor: Institut Pertanian Bogor.

Junaedi A, Pribadi A. 2011. Hubungan Antara Hama Daun Arthroschista hilaralis dengan Aspek Iklim dan Pertumbuhan Pohon Jabon. Laporan hasil penelitian Balai Penelitian Teknologi Serat Tanaman Hutan. Riau: Balai Penelitian Teknologi Serat Tanaman Hutan.

Klapwijk MJ, Ayres MP, Battisti A, Larsson S. 2012. Assesing the impact of climate change on outbreak potential. In: Barbosa P, Letourneav DK, Agrawal AA (Eds), Insect Outbreaks Revisited. pp.429-450. Chiechester: John Wiley \& Sons Ltd.

Krisnawati H, Kallio M, Kanninen M. 2011. Anthocephalus cadamba Miq.: Ekologi, Silvikultur dan Produktivitas. Bogor: Center for International Forestry Reasearch.

Li Z, Zalucki MP, Yonow T, Kriticos DJ, Buo H, Chen H, Hu Z, Feng X, Furlong MG. 2015. 
Population dynamics and management of diamondback moth (Plutella xylostella) in China: the relative contributions of climate, natural enemies and cropping patterns. Bulletin of Entomological Research 106:197-214. doi: https://doi.org/10.1017/S0007485315001017.

Macfadyen S, McDonald G, Hill MP. 2016. From species distributions to climate change adaptation: knowledge gaps in managing invertebrate pests in broad-acre grain crops. Agriculture, Ecosystem and Environment 253:208-219. doi: https://doi. org/10.1016/j.agee.2016.08.029.

Martawijaya A, Kartasujana I, Mandang YI, Prawira SA, Kadir K. 1989. Atlas Kayu Indonesia Jilid II. Bogor: Pusat Penelitian dan Pengembangan Hasil Hutan.

Mitchell C, Brennan RM, Graham J, Karley AJ. 2016. Plant defense against herbivorous pests: exploiting resistance and tolerance traits for sustainable crop protection. Frontiers in Plant Science 7:1132. doi: https://doi.org/10.3389/ fpls.2016.01132.

Mulyana D, Fahmi I. 2011. Panduan Lengkap Bisnis dan Bertanam Kayu Jabon. Jakarta: Agromedia.

Nair KSS. 2007. Tropical Forest Insect Pest: Ecology, Impact and Management. New York: Cambridge University Press. doi: https://doi. org/10.1017/CBO9780511542695.

Orwa C, Mutua A, Kindt R, Jamnadass R, Anthony. 2009. Agroforestry Database: A Tree Reference and Selection Guide Version 4.0. Tersedia pada: http://www.worldagroforestry.org/sites/treedbs/ [diunduh 2 April 2017].

Peltonen M, Heliovaara K. 1998. Incidence of Xylechinus pilosus and Cryphalus saltuarius (Scolytidae) in florest-clearcut edges. Forest Ecology and Management 103:141-147. doi: https://doi.org/10.1016/S0378-1127(97)00187-4.

Pickering DI. 1997. The influence of fire on west coast grasslands and concerns about its use as a management tool: a case study of the Oregon silverspot butterfly Speyeria hippolyta (Lepidoptera: Nymphalidae). In: Greenlee JM (Ed.), Proceedings of The $1^{\text {st }}$ Conference on Fire Effects on Rare and Endangered Species and Habitats (13-16 November 1995). pp. 37-46 USA: International Association of Windland Fire.

Pribadi A, Anggraeni I. 2011. Pengaruh temperatur dan kelembaban terhadap tingkat kerusakan daun Jabon (Anthocephalus cadamba) oleh Arthroschista hilaralis. Jurnal Penelitian Hutan Tanaman 8:451-458. doi: https://doi. org/10.20886/jpht.2011.8.1.1-7.
Price PW. 1991. The plant vigor hypothesis and herbivore attack. Oikos 62:244-251. doi: https:// doi.org/10.2307/3545270.

Sari RK, Armilasari D, Deded, Nawawi S, Darmawan W, Mariya S. 2014. Aktivitas antiproliferasi ekstrak jabon putih (Anthocephalus cadamba Miq.) terhadap sel kanker payudara dan serviks. JurnalIlmudan Teknologi Kayu Tropis 12:91-100. SAS Institute. 2010. SAS/STAT User's Guide, Version 9.1.3. Cary: SAS Institute.

Slik JWF. 2006. Trees of Sungai Wain. National Herbarium Nederland, Leiden University Branch, Leiden, Belanda. Tersedia pada: http:// www.nationaalherbarium.nl/Sungaiwain [diunduh 5 Oktober 2016].

Speight MR, Hunter MD, Watt AD. 2008. Ecology of Insect: Concepts and Application. West Sussex: Wiley-Blackwell.

Sudrajat DJ. 2015. Karakteristik Tempat Tumbuh, Keragaman Genetis, dan Potensi Sumber Benih Jabon Putih. Bunga Rampai Teknologi Pembenihan dan Pembibitan Jabon Putih (Neolamarckia cadamba (Roxb.) Bosser). Bogor: Forda Press.

Susanty SC. 2014. Bioekologi Hama Arthroschista hilaralis (Lepidoptera: Pyralidae) pada Tanaman Jabon (Anthocephalus cadamba Miq.). Tesis. Bogor: Institut Pertanian Bogor.

Thapa RS. 1970. Bionomic and control of laran defoliator, Margaronia hilaralis Walk. (Lepidoptera: Pyralidae). The Malayan Forest 33:55-62.

Thapa RS, Bhandari RS. 1976. Biology, ecology and control of Kadam defoliator, Arthroschista hilaralis Walk. (Lepidoptera: Pyralidae) in plantation in West Bengal. Indian Forester 102: 333-401.

Unterstenhofer G. 1963. The basic principles of crop protection field trials. Pflanzenschutz Nachrichten Bayer 16:81-164.

Utami S, Kurniawan A, Suparman M. 2011. Hama yang Menyerang Beberapa Tanaman di Kawasan Hutan dengan Tujuan Khusus (KHDTK) Kemampo Provinsi Sumatera Selatan. Laporan Hasil Penelitian. Palembang: Balai Penelitian Kehutanan Palembang.

Wylie FR, Speight MR. 2012. Insect Pest in Tropical Forestry $2^{\text {nd }}$ edition. Cambridge: CABI. doi: https://doi.org/10.1079/9781845936365.0000. 